\title{
A Case Study in Microfilming Documents
}

\section{The NSDAP Hauptarchiv}

In 1959 the Hoover Institution microfilmed approximately one hundred sixty shelf feet of captured documents which constituted the so-called Hauptarchiv of the German National Socialist Party. At the time, these documents reposed in the Berlin Document Center. The experiences of the staff in carrying forward this project, as well as in preparing a published guide to the archive, are described. The organization and historical development of the archive are outlined, and its value to scholarship is delineated.

$\mathrm{O}$

VER THE YEARS, the Hoover Institution has devoted much effort to rescuing historically significant archival material from dispersal or obliteration, and success has often hinged on timely action in far-off places. The Hoover Institution has striven, at the same time, to turn over this raw material to the international community of scholars with a minimum of delay and in a format which realistically takes into account the requirements of research. It is not surprising that these two objectives are only partially compatible in such "rescue operations" which, by their very nature, preclude elaborate preliminary planning and close supervision in the acquisition of the material. The microfilming of Collection NSDAP Hauptarchiv provides a case in point and illustrates an attempt to reconcile this double mission.

In the spring of 1958 the danger loomed large that Berlin might again be cut off from the west and that the Berlin

Dr. Heinz is on the staff of the Hoover Institution at Stanford University.
Document Center, administered by the U.S. Department of State, might find itself in an exposed position. The Document Center in Berlin had been established by the U.S. Army at the close of World War II as a repository for those captured German documents which focused on the National Socialist Party (Nationalsozialistische Deutsche Arbeiterpartei, or NSDAP) and which might have to be requisitioned for the war trials and denazification proceedings. It was becoming increasingly clear that these documents were valuable not only for such short-range political purposes but also for the work of historians and social scientists. Under these circumstances, the Hoover Institution was encouraged by the State Department as well as by individual scholars to help save the documents for research and strengthen its existing collections on $\mathrm{Na}$ tional Socialism in the process. Since the originals could not be transferred (their return to the German Federal Republic in the coming years had been guaranteed), the only alternative was 
to raise funds for microfilming portions of the Berlin Document Center's collections. ${ }^{1}$

An on-the-spot inspection by a staff member led to the decision to film the entity known as Collection NSDAP Hauptarchiv. Although, on cursory examination, not all the material appeared of equal historical value, the desire to preserve the coherence of the collection, combined with the difficulty and expense of making a selection at a distance of six thousand miles, finally weighed the scales in favor of unselective microfilming.

The systematic microfilming of an archive covering approximately one hundred sixty shelf feet and consisting of extremely heterogeneous material that ranged from stickers and postcards through leaflets, newspaper clippings, correspondence, and pamphlets to bound files and whole newspapers presented serious technical problems. However, since the material was divided into 1,421 numbered folders, grouped into twentynine numbered topics, with titles inscribed on each folder, the sequence to be followed in the filming was self-evident. Heedful of eventual library use, the Hoover Institution insisted that all precautions be taken to ensure that the clear labeling carry over to the film. The burden of all the technical preparation (which included the time-consuming task of transcribing the titles from the unfilmable folder covers to filmable little slips) was generously carried by the personnel of the Berlin Document Center. As a result, the cost of the film-

\footnotetext{
${ }^{1}$ In effect, the Hoover Institution's microfilming project served as a sort of pilot operation; in subsequent years, many of the Berlin Document Center's other collections were also filmed, notably by the National Archives. As of now, the only original documents retained by the Berlin Document Center are those making up its vast "Biographic Collection"; the rest have been turned over to the German government. A positive copy of the entire microfilm of Collection NSDAP Hauptarehiv was given to the State Department, which deposited it at the National Archives. The Hoover Institution also microfilmed the Himmler Collection and selected parts of the Streicher Collection at the Berlin Document Center, though these are not directly related to Collection NSDAP Hauptarchiv.
}

ing was restricted to that of the camera process itself.

Inasmuch as funds were limited and the primary objective was to complete the project, sometimes convenience of library use took second place. The main economy measure was filming by flowcamera, which automatically reproduces both sides of the page and therefore needs little manual assistance. There were several unfortunate consequences: well over half the back pages remained blank, thus cutting down the size of the frames unnecessarily (and forcing the user to invert the frame when it was not blank). At the same time, the flow-camera made no allowance for counting frame numbers. Worst of all, it could not handle oversized or bound material scattered through the folders. Whenever this type of material was found, it had to be removed from its proper sequence and filmed at the end by a flat-bed camera, with the result that a large number of folders were split up on separate reels of microfilm. This splitting-up process was aggravated by the wholly unwarranted economy measure on the part of the German microfilm company of continuing the filming to the very end of the roll rather than making a break after the last complete folder. From the point of view of preservation, these unwelcome features were of small consequence, and the serious stumbling blocks created for the eventual user were difficult to gauge during the execution of the project.

After several months of correspondence and long-distance instructions, microfilming actually began in early 1959 , and by the end of that year the 1,421 folders had been filmed. To its dismay, the Berlin Document Center then discovered that a block of nearly five hundred folders (labeled Folders 14261923) had been separated from Collection NSDAP Hauptarchiv some years before it was shown to the Hoover Institution's representative, although there was no doubt that it had once formed 
part of the collection. By good fortune, the Hoover Institution was able to raise sufficient funds for the additional filming, which in the end nearly doubled the size of the original operation. This material, which had not been subjected to even the most superficial evaluation by the Hoover Institution, proved to be by far the most significant documentation.

It was only after the 134 reels of microfilm were safely in the custody of the Hoover Institution and the collection could be scrutinized as an entity that the collection's spurious coherence became obvious. The suspicion that it had not survived intact from the days before German defeat was confirmed by the Berlin Document Center, which made it clear that it had received the material in such a state of disarray that a new organization had to be imposed on it by the Center's personnel a few years after the end of the war. In the light of this information, it was obvious that the Berlin Document Center's labeling might prove inadequate from the point of view of research.

The decision was made to compile a guide to the collection that would alleviate the most serious shortcomings of the microfilms for scholarly purposes. The Guide ${ }^{2}$ has sought to accomplish this objective in several ways. The technical difficulties presented by the microfilms were remedied by pinpointing the location of the folders scattered on the different reels. The absence of frame numbers was compensated by a rough count of frames per folder, a most essential step since folders varied widely in length (from one to over a thousand pages) and folder titles gave no clue how much material to expect. Beyond supplying this purely technical information, the Guide gave an opportunity to indicate major cross-references to persons or events and to simplify the loca-

'NSDAP Hauptarchiv: Guide to the Hoover Institution Microfilm Collection, compiled by Grete Hein and Agnes F. Peterson ([Hoover Institution Bibliographical Series, XVII] Stanford, Calif.: 1964). 187p. tion of documents by means of an index to persons and organizations. At the same time the most misleading folder titles could be rectified, supplementary information as to contents given, and individual items of particular interest to which the titles made no allusion highlighted.

Even the completion of this Guide, based on the scanning of the nearly two thousand folders, postponed unduly making the microfilms accessible to research. However, the monumental task of analyzing two hundred forty thousand frames and describing the heterogeneous contents assembled in many of the folders could not even be considered, given the limitations of time and personnel. What is more, it became clear that only the closest scrutiny of the entire collection could alert the analyzer to the relevance of seemingly trivial pieces of documentation and the importance of obscure figures. In truth, since folders and topical groupings could not be relied upon to reflect the intentions of the original collector, a thorough exploitation of the collection would have amounted to cataloging informally tens of thousands of individual items, the equivalent of a small library. Only in this manner could individual items, which had been cast adrift from their mooring and could no longer be fitted back in their proper place on the microfilm, be brought to the attention of the researcher. To take but one more lighthearted example, it is unlikely that anyone interested in Hitler or the Hitler Putsch would consult the "Miscellaneous" folder headed "Georg Reindl," and yet he would find there a fascinating document, the bill of fare for Hitler's substantial breakfast (two eggs, one tea, two slices of bread, and a liver sausage, with a glass of mulled wine) on the very morning of the Hitler Putsch, as well as bills for his followers' revelry on the previous night. These originals had been preserved by Georg Reindl, the brother of the owner of the famous 
Buergerbraeukeller, and brought to the Hauptarchiv in 1937; on the strength of this donation, Reindl won a recommendation as manager of a government canteen.

To a greater or lesser extent, these are problems facing all persons and organizations presently opening up to research the vast body of captured German documents and other documentation thrown into the public domain through the accidents of history. Various intermediary solutions, from accurate cataloging to no identification at all, are being tried out. Only a coordinated effort between librarians and individual scholars subjecting small portions of these collections to informed and perceptive scrutiny can, however, in the course of time, produce the kind of identification which will make the documents genuinely useful and accessible. Even then, the structural rigidity of microfilms will prevent correction of organizational flaws (misplacement or improper grouping of items) in archival material in the light of later knowledge, and the researcher cannot be spared the labor of reassembling bits of documentation scattered over various microfilms.

Since there was no possibility of accurately identifying the contents of the entire collection, an attempt was made, finally, by the compilers of the Guide to reconstruct how far the microfilms corresponded to a pre-existing set of documents and to retrace the steps whereby Collection NSDAP Hauptarchiv evolved to its final shape at the Berlin Document Center. The major pieces of the puzzle could be fitted together with the help of the fragmentary administrative file of the NSDAP Hauptarchiv, ${ }^{3}$ which was microfilmed as the concluding folder of the collection (and whose very existence as a result did not become known at the Hoover Institution until two years after the project's approval).

The eleven-year history of the NSDAP

\footnotetext{
${ }^{3}$ Folder 1923 I and II of Collection NSDAP Hauptarchiv.
}

Hauptarchiv can be quickly outlined. From its founding in February 1920 until Hitler's seizure of power, the National Socialist Party had no formal archival repository. For some years in the 1920's the party maintained a clipping archive from the National Socialist press and from that of political opponents. In 1928 the party purchased the nationalist-oriented Rehse Archive on contemporary history. In the last years of the Weimar Republic, at the height of the parliamentary struggle for power, party headquarters organized a centralized archive for supplying up-to-date information on National Socialist views and those of competing parties and for filing sample copies of political leaflets. Less than a year after Hitler's consolidation in power, in January 1934, an archive with a less functional and longer-range objective was founded at the initiative of one of the official propaganda agencies, the Reichsschulungsamt, from whose staff the archive's first director, Dr. Erich Uetrecht, was selected. First located in Berlin, it was moved in October 1934 to permanent quarters in Munich. In 1935 it was made directly responsible to Rudolph Hess, Hitler's deputy, and given a vague authority over the Rehse Archive (which, however, retained autonomy to the end of the Third Reich). In 1939 it was formally given jurisdiction over all material pertinent to the history of the NSDAP and became the main administration of all party archives as well as the Fuehrer's personal archive.

Although the archive proper constituted the core of the NSDAP Hauptarchiv, it operated as a research library, collecting all books relating to National Socialism, German and foreign newspapers and periodicals, and government documents. It provided reference services to party leaders and staged special pictorial exhibits on Bolshevism, the Jews, and phases of the history of the National Socialist movement. Since the key personnel of the Hauptarchiv quali- 
fied more by faithful party service than by technical competence (it numbered no trained archivist or librarian among its staff), problems of sorting and cataloging continued to plague the organization and were never satisfactorily resolved.

In the fall of 1943 the Hauptarchiv's second and last director, Arnold Bruegmann, supervised the partial evacuation of the archive from bomb-scarred $\mathrm{Mu}$ nich. (The wisdom of the decision was confirmed in January 1945 when the director had to report to his superior, Hitler's deputy Martin Bormann, that the Munich building had burned to the ground, that he had no function left, and that he therefore asked to be transferred to military duty.) Evacuation depots were chosen in three small Bavarian Towns. A steel vault in Passau served to protect a few treasured pieces. A courthouse and a farm in Neumarkt-St. Veit were chosen for the bulk of the archive proper, while voluminous periodical and newspaper files went to Lenggries. Records in the main accession book kept by the archival custodian in Neumarkt-St. Veit stop in March 1945; new items had been added to the collections up to that moment.

For the final chapter in the story of the Hauptarchiv, there are two sources of information: a report drawn up in 1951 by Dr. Bruegmann and an investigation carried out in 1953 by Dr. Anton Hoch, archivist of the Institut fuer Zeitgeschichte in Munich, at the request of the Berlin Document Center. Both of these lead to the conclusion that nothing remained of the Hauptarchiv's organized collections except what was found in the Passau and Neumarkt-St. Veit depots by the Fourteenth Armored Division of the U.S. Army in April 1945 and brought to Berlin at the end of the year. The original personnel had rapidly dispersed, apparently preferring to cut loose from such incriminating associations, and reports from available staff members on the final fate of the archive were con- fused and conflicting. The one person who might have possessed accurate information on the contents of the evacuation depots, namely the archival custodian Rolf Heine, had volunteered for military duty and was killed in action in the last days of the war. According to Dr. Bruegmann, little was willfully destroyed, but some valuable individual items were removed. One of these, the Bormann notes on Hitler's table talks, was certainly sold privately to a publisher and emerged in book form. Others may have remained in private hands, for instance the file on the generals' revolt of July 1944, which was received at Neumarkt-St. Veit shortly after the event and carefully itemized by Rolf Heine. Of the documents specifically listed in the Hauptarchiv's administrative files and in the main accession book kept at Neumarkt-St. Veit from August 1944 to March 1945, some are definitely not in the microfilms. ${ }^{4}$ The Hoover Institution is still exploring the possibility that substantial sets of documents from the Hauptarchiv might unwittingly have been incorporated in other collections of captured German documents or local German and Austrian libraries. ${ }^{5}$ At the present time, one can state only that the microfilms at the Hoover Institution are the collection's ultimate repository, now that the originals have been turned over

\footnotetext{
4 The files of the Wehrpolitisches Amt, the Reichsrechtsamt, and the N.S. Reichstagsfraktion are certainly missing. So are the sizable collections of leaflets, posters, postcards, and records stored at Neumarkt-St. Veit, which complemented the other historical documents. A close examination of the Hauptarchiv's lists on Marxist and leftist parties reveals that a good part of this material has gone astray. Other large files not directly related to the Hauptarchiv's main collecting efforts, such as the files of the Allgemeiner Deutscher Gewerkschaftsbund and those of the Reichs-Fluechtlings-Hilfswerk and of the underground Austrian NSDAP Archive, suffered a similar fate.

s Some Hauptarchiv documents have indeed turned up in the Library of Congress's Rehse Archive collection, a natural confusion, since both the Rehse Archive and the Hauptarchiv were officially party archives. The most important is the main accession book (or "Bestandbuch") mentioned above. It is quite possible that some material found its way into other National Socialist collections at the Berlin Document Center, notably the so-called Schumacher material, the collections of the Reichsorganisationsleiter and the Reichspropagandaleitung der NSDAP, and the Streicher files.
} 
to the Bundes Archiv of the Federal Republic in Coblenz and the Bavarian State Archive in Munich, where they may well in the course of time be fitted into an entirely different pattern. ${ }^{6}$

In view of the short life span of NSDAP Hauptarchiv and the period of chaos and confusion to which the material was subjected between its removal from Munich and its reorganization at the Berlin Document Center, it is small wonder that there emerged no exact correspondence between the files and documents of the Hauptarchiv and the Berlin Document Center's 1923 folders. Nevertheless, an intensive study of all available sources of information leads to the conclusion that the individual documents and files considered prize possessions by the Hauptarchiv itself were preserved, although generally not under the headings and groupings originally foreseen. From another angle, Collection NSDAP Hauptarchiv contains much direct evidence of having been gathered by the staff of the Hauptarchiv; when such evidence is lacking, there is usually strong reason to believe that the material fitted into the over-all collection pattern.

The reorganization of the material at the Berlin Document Center into twenty-nine subject groupings (Folders 1-1421, Folders 1422-1425 non-existent) and eight government agencies, plus the Hauptarchiv's own files (Folders 14261923) was inevitably carried over into the microfilms. Unfortunately this new arrangement obscures the original contours of the Hauptarchiv and makes it rather difficult to ascertain the areas of concentration and the scope of the historical archive proper. These can, how-

\footnotetext{
- The Bundes Archiv presently stores the folders in its possession (Folders 1-1421, 1921-1923) as Collection NS 26 with the exception of the material on the Deutsche Demokratische Partei, which has been integrated with other of this party's material at the Bundes Archiv. The Bayerisches Hauptstaatsarchiv in Munich has thus far left intact Folders 1426-1920, which it received in 1961, and has stored them as a unit under "Sonderabgaben."
}

ever, be reconstructed to some extent on the basis of the administrative files and of the filmed material itself.

Dr. Uetrecht, the first director of the Hauptarchiv, expressed its orientation quite emphatically: "The spotlight of the collecting activity is on National Socialism: antecedents, founding, early days, days of struggle (election campaigns, court proceedings, organizations, outlawings, seizure of power), history of the symbols, etc.; records of the Gau, district, and local party organizations; opposition movements and parties," and the ultimate goal of making the Hauptarchiv "the central repository of the written and documentary material of the NSDAP and its subdivisions, the source and yardstick of Germany's future historiography." 7

As to the organizational scheme of the archive proper, the various surveys and lists compiled for administrative purposes in 1942 and 1943, before and after evacuation, make it fairly clear that a consistent over-all pattern had not as yet been chosen. The party history in its narrowest sense was chronologically divided into early days, the Hitler Putsch, the leaderless period, and the years of construction. There was the topical arrangement of material on Hitler, the "Gau" organizations and other party subdivisions, the nationalist movements, leftist political parties, and important personalities. Lastly, grouping by provenance was applied to archives taken over as separate entities; to large sets of papers donated by individuals (among the most important are those of Anton Drexler, Dietrich Eckart, Alfred Brunner, Abbot Schachleiter, and Houston Stewart Chamberlain); and to the files of certain defunct party organizations, such as the Nationalsozialistische Studentenbund, the Nationalsozialistische Reichstagsfraktion, the Wehrpolitisches Amt, and the Reichsrecht-

? Folder 1923 I. 
samt. ${ }^{8}$ Above all, the large body of files from the various police and judicial agencies was stored as a unit. ${ }^{9}$

It must be stressed that the Hauptarchiv made no concerted effort to preserve the records of the party as a ruling elite in a totalitarian state. Characteristically, the archival custodian concludes his 1942 survey of documents for the new director with the remark: "There is very little material on the 'Reichsleiter'" (The Third Reich's leading figures, aside from Hitler himself). It is probably no accident that Munich, which held such close ties to the party's past, was chosen as the permanent headquarters in preference to the current center of power in Berlin. Thus it is not surprising that the archive's most irreplaceable documents, the very ones which found their way to the Berlin Document Center, were those that reconstructed the image of the party as a persecuted sect.

The story of this sect's prophets, its savior, its first apostles and martyrs, its small band of faithful, as well as the origins of its sacred doctrine, is vividly told and thoroughly documented. There are the personal recollections of the "old guard"; ${ }^{10}$ it was then as much a matter of pride to have been one of the founding members (witness the furor aroused by the disappearance of the card file

\footnotetext{
8 These last three files, as mentioned above, are not microfilmed in Collection NSDAP Hauptarchiv, although they were evacuated to Neumarkt-St. Veit.

- These government files were so successfully isolated from the rest of the collections that they nearly missed being filmed as part of Collection NSDAP Hauptarchiv, since they constituted the block of folders misplaced by the Berlin Document Center. Inasmuch as the Hauptarchiv gave no guidance at all how to divide them chronologically or topically, they were simply grouped by provenance at the Berlin Document Center. The separation of these documents from the rest of the material has now been formalized except on the microfilm: the Bavarian State Archive has been given custody of the files from the various Bavarian government agencies.

10 Specifically, these "memories of fighting days" were solicited by the Hauptarchiv for the Munich revolution, April 1919, for participation in the Hitler Putsch, and for a personal history of political activities from members of the different Gau (including the Austrian) organizations. There are hundreds of these reports from obscure party members.
}

containing the first fifty-five thousand names) as it was after 1945 to have been an early anti-Nazi. There are the records of the founding of party organizations in Munich and elsewhere; ${ }^{11}$ the private papers of early party leaders; ${ }^{12}$ Hitler's personal memorabilia; ${ }^{13}$ and the documents connected with the November 1923 uprising, the so-called Hitler Putsch, ${ }^{14}$ which supplied the party with its martyrs-the dead, wounded, and imprisoned. The story is also told in terms of National Socialism's intellectual forebears, the burgeoning racist and nationalist sects of prewar days, through

11 These cover the complete minutes of the two organizations which were the immediate predecessors of the NSDAP, namely the Freier Politischer Arbeitszirkel, founded in the closing days of World War I, and the Deutsche Arbeiter Partei, both chaired by Anton Drexler, as well as the files of the closely related Deutschsozialistische Partei under the leadership of Alfred Brunner. Reports on Hitler's first emergence in the party, elaboration of the party program, and the first membership lists fill in the details of the NSDAP's beginnings.

12 Besides the papers of Dietrich Eckart, Anton Drexler, and Alfred Brunner, there are contributions from lesser party luminaries like Lauboeck (Hitler's first private secretary) and the early party secretaries and treasurers Wiegand, Schuessler, Lotter, and Riedl. From other parts of Germany, significant papers were turned over by Ludolf Haase, Adolf Gimbel, and Hermann Fobke. Not a single document stems from Himmler or Rosenberg, and the personal items turned over by Goering and Goebbels are of slight interest.

${ }^{13}$ The documentation on Hitler again emphasizes the early days-family Schicklgruber's genealogy and private papers, records of Hitler's childhood and school days, his military records, his water colors (all his originals were tracked down and collected by the Hauptarchiv and are reproduced on microfilm). Hitler's political career is reflected in his well-known letter on the Jewish question (1919), notes and memoranda on various themes for his early speeches, the complete text of a number of his speeches, beginning with December 1919, documents on his Landsberg prison days, and his 1932 appointment as a Braunschweig official which assured his German citizenship. Of course the government files throw a great deal of light on Hitler's political career, but the Hauptarchiv's source material adds somewhat to this picture.

14 In addition to the court records and lists of wounded and injured, there are the extensive personal recollections solicited or accidentally acquired by the Hauptarchiv (as in the case of Mr. Reindl or the widow of Max von Scheubner-Richter, one of the Putsch victims). The staff of the Hauptarchiv undertook some research of its own on the subject; there is also the inside account of Professor Georg Fuchs, then a high-ranking Bavarian official who collaborated with Frick and Poehner. The papers of NSDAP lawyers Schramm and Roder are of special interest. Here again, the government files give a vast amount of additional information. 
the personal papers of their spokesmen, which were then still extant. ${ }^{15}$

There also emerges however, the more earthy image of a political minority, with its vigorous and ramified grassroots organizations, ${ }^{16}$ its many-headed press ${ }^{17}$ its collisions with an antagonistic and repressive government "system." 18 No veil is drawn over internal rifts and struggles during the time of Hitler's imprisonment and the existence of opposition groups in later years, ${ }^{19}$ nor

15 The Hauptarchiv's collection on the so-called "Voelkische Bewegung" which covers all these groups is systematically listed in the administrative files, but was dispersed at the Berlin Document Center. The most important files for the late nineteenth and early twentieth century are those of the Guido von List Gesellschaft, the Reichshammerbund and Germanenbund, and the Deutschvoelkischer Schriftsteller Verband; for the Austrian nationalist movement, the Ritter von Schönerer papers are of value. For the period of postwar turmoil in Bavaria, there are the Deutsch-voelkischer Schutz- und Trutzbund and the Thule Gesellschaft, which was so intimately tied to the NSDAP's own origins. Of equal interest are the files of the paramilitary Bavarian groups, such as Bund Oberland Freikorps Rossbach, Organisation Escherich, and other citizen's militias. It is probable that the complete files of the central German veterans' organization, the Kyffhaeuser Bund, were acquired by the Hauptarchiv because of its part-military, part-political role.

16 The original documents on early membership (such as the handwritten list of ten thousand members enrolled in Germany in the last months before the Hitler Putseh) and on the organizational structure and finances of the party's Gau, district, and local groups were carefully preserved by the Hauptarchiv. Aside from Munich and its suburbs, there is valuable material on the Berlin, Hannover, and Kiel organizations, as well as sets of complete party files (those of the little Bavarian town of Ottobrunn span 1925-1938 and those of Gau Ostmark 1924-1931). The major historical files of the Nazi subdivisions ("Gliederungen" and "angeschlossene Verbaende") are those of the Hitler Youth, the SA, and the Nationalsozialistische Betriebszellenorganisation. The SS is not covered in any detail. The government files supply considerable additional information on all these organizations, including the SS, much of it primary source material confiscated from the organizations' headquarters in Bavarian localities.

17 In 1937 the Hauptarchiv made a survey of the National Socialist press and received basic historical information on over 200 Nazi newspapers.

18 The Hauptarchiv appealed to party members and government agencies to turn over police and court records on these clashes and collected documentation on party demonstrations, defiances of various government regulations, and so on.

19 For the leaderless period, the documents on the Deutsche Freiheitsbewegung, the Grossdeutsche Volksgemeinschaft, the N.S. Freiheitsbewegung, and the Voelkische Block are the most revealing. The court records of the trial of Roehm, Ludendorff, and other nationalist leaders (the 1924 Frontbann trial) complement these documents. For the last years of the Weimar Republic the internal opposition groups led are the tactics used to gain power ${ }^{20}$ in the face of harassments from bourgeois and leftist political opponents ${ }^{21}$ glossed over.

As a link between these two levels there runs the anti-Semitic leitmotif..$^{22}$ It serves as a cornerstone of the National Socialist articles of faith inherited from nationalist predecessors and as a tactical weapon in the Bavarian political arena. The same applies to a lesser extent to the themes of anti-Communism and the rejection of World War I defeat, which are reiterated on both the doctrinal and the practical political level. ${ }^{23}$

by Stennes and Strasser are given some attention. The 1934 Roehm revolt, on which the Hauptarchiv received important documentation, is the only material on internal party opposition during the Third Reich.

${ }^{20}$ The correspondence of the central party headquarters with parliamentary candidates is very extensive, as is election material of all sorts issued by the Reichspropagandaleitung. The leaflet and poster collection is supplemented, more or less by chance, by the complete files of the Munich Police's press section, which had to censor all political items distributed in Munich. Clashes with Communists and the Socialists' paramilitary Reichsbanner are amply documented in the police and court records.

21 Detailed lists of material from these parties are to be found in Folder 1923 II. As mentioned earlier, some of the most interesting documents from the list on the Communist and Socialist parties are not included in the microfilmed collection. The Munich Police also provides a great deal of information on Communist tactics and on the organization of the Bavarian Socialist Party (and the associated Reichsbanner). The complete archive of the Deutsche Demokratische Partei (known as Deutsche Staatspartei after October 1930) from its founding in December 1918 to its dissolution May 1933, which the Hauptarchiv had taken over, does appear in its entirety on the microfilm.

2 No systematic collection on the Jewish question was undertaken by the Hauptarchiv, although it staged an exhibit on the subject in 1939. Material ranges from anti-Semitic leaflets, tracts, and philosophical treatises to lawsuits involving Jews and party members. It even includes historical documents going back to the eighteenth century on the position of Jews in Poland, Bohemia, and Austria. Closely related to the Jews as ideological targets were the Freemasons, on whom the Hauptarchiv also collected incriminating documentation.

${ }^{23}$ Much of the historical nineteenth-century documentation on Communism was collected from this doctrinal point of view. One unexpected item is a set of Czarist police records on 67 Communist agents abroad (among them figures like Lenin, Trotsky and Jogiches). The material on the Munich Raeterepublik must also be viewed as anti-Communist ammunition. Concern regarding the responsibility for World War I defeat is reflected in the Cossman-Gruber trial documentation, which marshals all the "stabin-the-back" arguments. Interest in the Ruhr oceupation stems from this same rejection of the Versailles treaty. 
The Hauptarchiv relied on its official jurisdiction over historical documentation on the NSDAP to lay claim to important government records on National Socialism and related nationalist movements, as well as on the major leftist parties. As the self-image delineated above is primarily based on developments in Bavaria, so the main government documents were derived from Bavarian sources: the Munich police (after 1933 known as the Bavarian political police), the Bavarian Ministry of the Interior, and the Munich courts. In volume, the files of the Munich police alone are about equivalent to those on the history of the NSDAP from 1919 to 1933 from nongovernmental sources. These government files not only constitute the main contemporary (pre-1933) documentation ${ }^{24}$ on the party's history, but act as a fascinating counterpoint to the party's self-idealization.

In attempting to assess and control the danger of subversion from political extremists, the Bavarian police agencies spied on public and closed meetings, drew up reports on the general political situation and internal party disputes, and kept clipping files on relevant political issues. In connection with the innumerable acts of rowdyism and vandalism and the frequent clashes between National Socialists and members of leftist parties, which characterized the precarious democratic regime and blunted sensibilities towards political acts of violence in Germany, the police had to interrogate accused and witnesses, in the process eliciting extensive biographical information from these participants. This type of information spans the entire Weimar Republic. For the earlier years, the Hitler Putsch and the ensuing trial provide the focal point. In the later period, it is the prosecution of the par-

\footnotetext{
s4 The files were apparently not examined closely nor were they itemized by the Hauptarchiv. It is therefore likely that the documents have not been tampered with and are still in their original, contemporary shape.
}

ty's paramilitary organizations, particularly the SA and the Hitler Youth, which yields documentation through raids on the headquarters of these organizations and subsequent confiscation of their files. The records of the Nuremberg police are not nearly as complete in coverage and concentrate on the political career of Julius Streicher and his conflicts with the law as a result of the "Stuermer's" inflammatory and libelous texts. ${ }^{25}$

The bound files of the Bavarian Ministry of the Interior have a broader range, since they deal with the entire problem of political control of extremist parties by the Bavarian government, the government of other German states, and the central German government. Here the focus is on the National Socialist movement as a whole and Hitler as its leader rather than on individual party members and local organizations. The most revealing documentation of the Munich tribunal is the complete record for the trial of nationalist leaders accused of continuing Hitler's revolutionary aims during his imprisonment. Of value for reference purposes is the Munich tribunal's registry of political organizations (down to the quaint Kampfbundvereinigung Muenchner Eierhaendler), including the majority of the nationalist groups in Bavaria during the Weimar Republic. Of more limited interest are the court records involving National Socialist figures. Smaller police files (Berlin, Wuerttemberg, Braunschweig) complement the picture from the government point of view. ${ }^{26}$ The Reich ministries of Justice and of the Interior refused to countenance turning over wholesale their documents to the

\footnotetext{
${ }^{25}$ It is conceivable that the Nuremberg Police files are derived from another set of captured German documents, the Streicher Collection at the Berlin Document Center, now on microfilm at the National Archives, since these files never appear on any of the Hauptarchiv's own lists and bear no evidence of having belonged to its collections.

30 These government files were not organized by provenance at the Berlin Document Center but fitted into the twenty-nine topics.
} 
Hauptarchiv, which had to content itself with ascertaining the location of police and judicial files relevant to $\mathrm{Na}$ tional Socialist history.

The jurisdiction of the Hauptarchiv is no longer paramount once we leave the clearly delimited period when party and state were antagonistic institutions and come to the Third Reich, the "years of construction" (to use the Hauptarchiv's own term). Certain topics are of course carried through chronologically beyond 1933 , but only a few areas shed light on the party in Hitler Germany: the record of the annual party meetings, held up to $1939,{ }^{27}$ correspondence from National Socialists or sympathizers in other countries, and the relations of the party with the Catholic and Protestant churches. For the war years, there are the reports on the contributions of various party subdivisions to the war effort. The best that can be said of the remainder of the material is that it may throw some incidental light on conditions in Germany, but it is too fragmentary to deserve detailed analysis.

This description of the scope, special

$n$ The organizational red tape for the September 1939 party meeting is as fully documented as for those held previously, down to the last arrangements for hotel reservations and traffic control. There was only one fatal organizational flaw: the meeting had to be canceled because of the outbreak of World War II. emphasis, and limitations of Collection NSDAP Hauptarchiv should serve to give some notion of what may be found in the 134 reels of microfilm now at the Hoover Institution. Though originally assembled in the interests of future National Socialist historiography, the collection in its present form may well bring fresh insights to the current reevaluation of German history between the two wars. Its distinctive contribution as a unit lies in the curious juxtaposition of two disparate elements: the contemporary documentary evidence (mainly from government sources) on the history of National Socialism during the Weimar Republic and the vision that the party had resurrected, at the height of its triumph, of its own roots, growth, and mission. Incompatible as this self-image was in many respects with the shocking realities of Nazi rule, it goes far in clarifying the third Reich's characteristic obsessions and delusions, which sparked its self-destructive dynamism.

It is hoped that the research to which Collection NSDAP Hauptarchiv gives impetus will vindicate the decision to make it available to the scholarly community and will in turn uncover new documentation which escaped notice in this preliminary inspection.

\section{USOE Statistics Questionnaires}

QuestionnaIres for the Survey of College and University Libraries, 1964-65, are expected to be mailed to participating libraries early in December 1965. The survey is conducted by the U.S. Office of Education. Participating libraries are requested to return the completed questionnaires as soon as possible, and no later than six weeks after receipt to enable early publication of the survey. Mailing of the questionnaires was delayed primarily to correlate the collection of data concerning library needs as they relate to Title II, Part A of the Higher Education Act of 1965.

In addition to information on resources held, and added, by the libraries during the year, the questionnaire seeks information on the number of periodical titles and also on serial titles held. A section on library activities will inquire whether bibliographies are completed, acquisition lists are circulated, and whether the library serves as a depository for federal, state, or other documents. Data is also to be collected on the mechanization of acquisitions procedures, serial records, circulation, and other activities. Another first-time section seeks an analysis of resources, and requests information of approximate percentages of the total collection devoted to the humanities and general works, social sciences, physical sciences including mathematics, biomedical sciences, and technology (engineering). 